\title{
Kegagalan Penerapan Good Corporate Governance Pada Perusahaan Publik Di Indonesia
}

\author{
Oleh: Djohari Santosa \\ Dosen FH UII Yogyakarta \\ e-mail:djohari@fh.uii.ac.id
}

\begin{abstract}
This article aimed to study The Failure of Implementation of Good Corporate Governance (GCG) on Public Companies in Indonesia. Implementation GCG, specifically in public companies, is very important because it could enhanced corporate profit and shareholder gain in long term By using normative legal methods, this article demonstrated: First; GCG is a concept emphasizing the importance of the user right of financial statement to get the information accurately and timely; and the company management liability to provide the information accurately and perform the company fundamental value. Second; implementation GCG failed in Indonesia. It just because many public companies still hesitated to fully implement GCG. Third, Indonesia does not need more law. What is needed is a changed legal culture that will put to work these laws and institutions as they are designed to be used and commitment in every aspect of professional life to implement GCG.
\end{abstract}

Keyword: Good Corporate Governance and public companies

\section{Pendahuluan}

Corporate governance merupakan topik utama yang banyak diperbincangkan khalayak ramai selama beberapa tahun ini. Secara umum, kemampuan suatu negara untuk menarik modal asing sangat tergantung pada sistem corporate governance yang mereka anut dan sampai tingkat mana manajemen suatu perusahaan menghormati dan mematuhi hak-hak hukum para pemegang saham, lender, bondholders, dan non-controlling shareowners. Para investor pun tidak bersedia menanamkan modalnya pada perusahaan di suatu negara yang tidak memiliki sistem corporate governance yang efektif. ${ }^{1}$

\footnotetext{
${ }^{1}$ Jeswald W. Salacuse, "Corporate Governance in the New Country", Company Lawyer, Volume 25 (3), 2004, hlm. 69.
} 
Dengan demikian, tuntutan atas adanya penerapan Good Corporate Governance (GCG) merupakan salah satu isu untuk menarik minat masuknya pemodal asing ke dalam pasar modal suatu negara. Sehingga makin baik suatu negara menerapkan prinsip-prinsip yang ada dalam GCG merupakan indikasi adanya perlakuan yang baik terhadap pemodal. ${ }^{2}$

Kehadiran GCG di Indonesia sendiri merupakan salah satu solusi untuk menciptakan kegiatan berusaha yang kondusif dan dapat menghindarkan segala bentuk skandal dalam suatu perusahaan, terutama di Indonesia yang merupakan negara dengan budaya korupsi yang sangat tinggi. Dalam kenyataannya GCG hingga saat ini belum diterapkan sepenuhnya.

\section{Definisi GCG}

GCG merupakan suatu sistem pengelolaan perusahaan yang mencerminkan hubungan yang tersinergi antara manajemen dan pemegang saham, kreditur, pemerintah, supplier dan stakeholder lainnya. ${ }^{3}$

Corporate governance mengacu pada suatu prosedur yang dibuat dalam perusahaan yang memberikan kewenangan pada direksi untuk memberitahukan tentang fakta-fakta material keadaan investor dan stakeholder lain dan membuat keputusan yang efisien dan akurat dalam perusahaan. Dengan kata lain, corporate governance di sini menggambarkan tentang serangkaian aturan hukum yang mengatur tentang kewenangan dan kewajiban direksi, officer, dan pemegang saham. ${ }^{4}$

The 1992 Report of The Committee of the Financial Aspects of Corporate Governance mendefinisikan corporate governance sebagai "as the system by which companies are directed and controlled". Dari definisi di atas dapat dikatakan bahwa corporate governance bermakna sebagai suatu sistem di mana perusahaan itu diarahkan dan dikendalikan. The OECD Corporate Governance principles of 1999 mendefinisikan corporate governance dengan: ${ }^{5}$

${ }^{2}$ Hamud M. Balfas, Hukum Pasar Modal Indonesia, PT Tatanusa, Jakarta, 2006, hlm. 231

${ }^{3}$ Nindyo Pramono, Bunga Rampai Hukum Bisnis Aktual, PT Citra Aditya Bakti, Bandung, 2006, hlm. 87-88.

${ }^{4}$ Jeremy Charles Vanderloo, "Encouraging Corporate Governance for the Closely Held Business", Mississippi College Law Review, Volume 24, Fall 2004, hlm. 40.

${ }^{5}$ Nikolai Lazarev, "On Certain Issues of The Modern Corporate Governance Reform in Russia", International Company and Commercial Law Review, Volume 17 (5), 2006, hlm. 143. 
"Corporate Governance involves a set of relationship between a company's management, its board, its shareholder and other stakeholders. Corporate governance also provides the structure through which the objectives of the company are set, and the means of attaining those objectives and monitoring performance are determined."

Dari pengertian yang diberikan oleh OECD dapat dikatakan bahwa pengelolaan perusahaan yang baik adalah mengacu kepada adanya hubungan antara pihak manajemen, board of director, pemegang saham, dan juga pihak lainnya yang berkepentingan.

Dalam konteks perusahaan, istilah corporate governance diasosiasikan dengan kewajiban direksi kepada perusahaan untuk menjamin bahwa dirinya akan memenuhi semua kewajibannya sesuai dengan kewajiban yang dibebankan kepadanya dan juga menjamin bahwa kegiatan bisnis perusahaan tersebut akan dilaksanakan hanya demi kepentingan perusahaan semata. ${ }^{6}$

Kemudian, istilah corporate governance menjadi lebih luas lagi, tidak hanya meliputi kewajiban direksi terhadap perusahaan, tetapi kewajiban direksi kepada perusahaan secara keseluruhan, yang meliputi pemegang saham. Dalam hal ini direksi memberikan jaminan bahwa perusahaan akan memenuhi seluruh kewajibannya pada para pemegang sahamnya. Perusahaan akan dikendalikan dan dijalankan oleh direksi hanya dengan tujuan untuk menambah nilai kekayaan pemegang saham. ${ }^{7}$

Di Amerika Serikat, konsep corporate governance lebih bermakna pada tanggung jawab sosial perusahaan (social responsibility) dan perilaku etis para stakeholders yang di dalamnya termasuk para karyawan, pelanggan, supplier, kreditur, dan lain-lain. Di sini, perusahaan berperan sebagai trustee dan hubungan antara perusahaan dan para stakeholdernya harus didasarkan pada kontrak sosial, di mana perusahaan secara moral terikat pada constituency statutes untuk memperhatikan seluruh kepentingan dalam kelompoknya. ${ }^{8}$

Prinsip-prinsip pokok corporate governance yang perlu diperhatikan untuk terselenggaranya praktik GCG adalah Transparansi (Transparency),

\footnotetext{
${ }^{6}$ Kala Anandarajah, "The New Corporate Governance Code in Singapore”, Journal of International Financial Markets, Volume 3(6), 2001, hlm. 262.

${ }^{7}$ Ibid.

${ }^{8}$ Saleem Sheikh, "Introduction to the Corporate Governance Themed Issue", International Company and Commercial Law Review, Volume 9 (10), 1998, hlm. 267.
} 
Keadilan (Fairness), Akuntabilitas (Accountability), dan Responsibilitas (Responsibility). OECD menyusun prinsip-prinsip pokok tersebut ke dalam kategori hak-hak pemegang saham (the rights of shareholders), perlakuan yang adil bagi seluruh pemegang saham (the equitable treatment of shareholders), peranan stakeholders dalam corporate governance (the role of stakeholders in corporate governance), pengungkapan dan transparansi (disclosure and transparency), tanggung jawab direksi dan komisaris (the responsibility of the board). ${ }^{9}$

Sistem corporate governance yang baik memberikan perlindungan efektif kepada para pemegang saham dan pihak kreditur, sehingga mereka bisa meyakinkan dirinya akan perolehan kembali investasinya dengan wajar dan bernilai tinggi. Oleh karena itu, sistem tersebut harus juga membantu menciptakan lingkungan yang kondusif terhadap pertumbuhan sektor usaha yang efisien dan berkesinambungan. Dengan demikian, corporate governance dapat didefinisikan sebagai seperangkat peraturan yang mengatur hubungan antara pemegang saham, pengurus (pengelola) perusahaan, pihak kreditur, pemerintah, karyawan serta para pemegang kepentingan intern dan ekstern lainnya yang berkaitan dengan hak-hak dan kewajiban mereka atau dengan kata lain suatu sistem yang mengatur dan mengendalikan perusahaan. Sedangkan, tujuan corporate governance yaitu untuk menciptakan nilai tambah bagi semua pihak yang berkepentingan (stakeholders). ${ }^{10}$

Secara lengkap, GCG pada dasarnya merupakan suatu konsep yang menyangkut struktur perseroan, pembagian tugas, pembagian kewenangan dan pembagian beban tanggung jawab dari masing-masing unsur yang membentuk struktur perseroan. Konsep GCG ini juga menyangkut mekanisme yang harus ditempuh oleh masing-masing unsur dari struktur perseroan tersebut serta hubungan-hubungan antara unsurunsur dari struktur perseroan itu, mulai dari RUPS, direksi, komisaris, dan juga mengatur hubungan-hubungan antara unsur-unsur dari struktur perseroan dengan unsur-unsur di luar perseroan yang pada hakikatnya merupakan stakeholder dari perseroan. Unsur-unsur di luar perseroan tersebut yaitu negara yang sangat berkepentingan akan perolehan pajak

\footnotetext{
${ }^{9}$ Misahardi Wilamarta, Hak Pemegang Saham Minoritas dalam Rangka Good Corporate Governance, Program Pasca Sarjana, Fakultas Hukum Universitas Indonesia, Jakarta, 2002, hlm. 2-3

${ }^{10}$ www.fcgi.or.id/indonesia, diakses pada tanggal 16 Januari 2007.
} 
dari perseroan yang bersangkutan dan masyarakat luas yang meliputi para investor publik dari perseroan itu (dalam hal perseroan merupakan perusahaan publik), calon investor, kreditur dan calon kreditur perseroan. ${ }^{11}$

Jika dilihat secara umum, institusi dalam corporate governance sendiri mencakup internal ataupun eksternal perusahaan. Institusi eksternal meliputi agency regulatory seperti pemerintah, pasar modal di mana saham perusahaan itu didaftarkan, dan pengadilan yang mengakui adanya upaya hukum bagi pelanggaran aturan-aturan governance. Institusi internal adalah mekanisme yang berada di dalam perusahaan yang menentukan bagaimana perusahaan itu dijalankan. Institusi eksternal dan internal tersebut saling berhubungan satu sama lain semenjak mekanisme internal secara luas diatur dan ditentukan oleh institusi eksternal. Misalnya, hukum dan peraturan pemerintah mengatur secara spesifik tentang kewenangan dewan direksi dan dewan pengawas, hak-hak pemegang saham, dan kewajiban manajer. ${ }^{12}$

\section{Arti Pentingnya Komite Audit dan Komisaris Independen dalam Perseroan}

Masalah GCG saat ini sudah menjadi suatu kebutuhan bagi suatu negara atau perusahaan yang ingin masuk ke dalam pergaulan bisnis internasional. Seorang investor akan mau membeli saham dengan harga yang tinggi, salah satu indikatornya adalah apakah perusahaan (emiten) menerapkan prinsip GCG secara baik atau tidak. Dengan demikian, prinsip GCG telah menjadi suatu prinsip yang sangat penting bagi keberhasilan pengelolaan perusahaan. ${ }^{13}$

Salah satu upaya yang dapat ditempuh dalam mewujudkan GCG dalam pengelolaan korporasi adalah dengan membentuk komisaris independen dan komite audit yang duduk dalam jajaran pengurus perseroan, terutama pada perusahaan publik (public listing company).

Komisaris independen adalah komisaris yang bukan merupakan anggota manajemen, pemegang saham mayoritas, pejabat ataupun

${ }^{11}$ Sutan Remi Sjahdeni, "Peranan Fungsi Kepengawasan bagi Pelaksana Good Corporate Governance," Reformasi Hukum di Indonesia Sebuah Keniscayaan, R.M. Talib Puspokusumo (ed), Tim Pakar Hukum Departemen Kehakiman dan Hak Asasi Manusia Republik Indonesia, Jakarta, 2000, hlm. 2.

${ }^{12}$ Jeswald W. Salacuse, op.cit., hlm. 78.

${ }^{13}$ Nindyo Pramono, op.cit., hlm. 79 
seseorang yang berhubungan secara langsung ataupun tidak langsung dengan pemegang saham mayoritas dari suatu perusahaan yang mengawasi pengelolaan perusahaan. ${ }^{14}$

Di dalam suatu perseroan, diwajibkan mempunyai sekurang kurangnya satu orang komisaris independen, yang berasal dari luar perusahaan serta tidak mempunyai hubungan bisnis dengan perusahaan atau afiliasinya. Komisaris independen ini diharapkan dapat menciptakan keseimbangan berbagai kepentingan pihak, seperti pemegang saham utama, direksi, komisaris, manajemen, karyawan, maupun pemegang saham publik.

Independensi bagi komisaris merupakan hal yang diharuskan dalam suatu perusahaan publik agar komisaris dapat menjalankan tugastugasnya dengan efektif. Agar suatu perusahaan menjadi efektif dalam melaksanakan tugasnya maka jumlah komisaris independen dalam perusahaan harus ditingkatkan. Definisi mengenai independensi di sini adalah di mana komisaris tidak memiliki hubungan dengan para pegawai yang terlebih dahulu bekerja di perusahaan tersebut, bebas dari hubungan kontraktual yang menguntungkan dan bebas dari hubungan keluarga yang dianggap dapat mempengaruhi independensinya. ${ }^{15}$

Dalam perspektif hukum terdapat tiga acuan yang menjadi landasan adanya komisaris independen. ${ }^{16}$ Pertama, acuan tentang kedudukan komisaris dalam suatu perseroan terbatas seperti yang diatur dalam Pasal 94-101 UUPT No.1/1995.

Kedua, ketentuan Pasal 80 UU No.8/1995 tentang Pasar Modal, yaitu tentang tanggung jawab atas informasi yang tidak benar dan menyesatkan, di mana komisaris termasuk pihak yang diancam oleh pasal tersebut, bila ikut menandatangani setiap dokumen yang berhubungan dengan penyampaian informasi kepada publik di dalam rangka pernyataan pendaftaran. Bagi setiap calon emiten yang akan mencatatkan saham di bursa efek, maka PT Bursa Efek Jakarta, mewajibkan adanya komisaris independen di dalam kepengurusan emiten tersebut.

\footnotetext{
${ }^{14}$ Indra Surya dan Ivan Yustiavandana, Penerapan Good Corporate Governance Mengesampingkan Hak-Hak Istimewa demi Kelangsungan Usaha, Kencana, Jakrta, 2006, hlm. 135.

${ }^{15}$ Daniel J.H Greenwood, “Enronities: Why Good Corporations Go Bad", Columbia Business Law Review, 2004, hlm. 839.

${ }^{16}$ Indra Safitri, Indonesia Market Links Network, 2-9-2002, hlm. 3.
} 
Ketiga, adanya pedoman yang dikeluarkan Komite Nasional GCG sehubungan kehadiran komisaris independen yang ada di perusahaan publik, di mana di bagian II.1 menyebutkan bahwa pada prinsipnya, komisaris bertanggung jawab dan berwenang untuk mengawasi kebijakan dan tindakan direksi, dan memberikan nasehat kepada direksi jika diperlukan. Untuk membantu komisaris dalam menjalankan tugasnya, berdasarkan prosedur yang ditetapkan sendiri, maka seorang komisaris dapat meminta nasehat dari pihak ketiga dan atau membentuk komite khusus. Setiap anggota komisaris harus berwatak amanah dan mempunyai pengalaman dan kecakapan yang diperlukan untuk menjalankan tugasnya.

Keberadaan komisaris independen sangat dibutuhkan oleh perusahaan-perusahaan di Indonesia baik BUMN maupun perusahaan swasta, khususnya PT Terbuka. Pengertian mengenai komisaris independen dapat dikategorikan dalam beberapa kriteria yaitu sebagai berikut: ${ }^{17}$

1. Dipilih dan diangkat secara independen

2. Penilaian objektif dan independen

3. Berasal dari luar perusahaan

4. Bebas dari pengaruh

5. Tidak ada hubungan afiliasi

6. Tidak memiliki kepentingan di perusahaan

7. Bertindak secara independen

8. Memiliki kompetensi dan integritas memadai

Penentuan dan kriteria komisaris independen haruslah berdasarkan

UUPT dan ditambah dengan ketentuan-ketentuan lainnya, seperti: ${ }^{18}$

1. Surat Edaran Ketua Bapepam Nomor SE-3/PM/2000 tanggal 5 Mei 2000

2. Keputusan Direksi BEJ Kep.399/BEJ/07/2001, tanggal 20 Juli 2001, dan

3. Surat Edaran BEJ Nomor SE-005/BEJ/09-2001, tanggal 24 September 2001 yang mengatur Tata cara Pemilihan Komisaris Independen.

${ }^{17}$ Antonius Alijoyo dan Subarto Zaini, Komisaris Independen, Penggerak Praktik GCG di Perusahaan, Penerbit PT Indeks Kelompok GRAMEDIA, Jakarta, 2004, hlm. 54.

${ }^{18}$ Chatamarrasjid, Penerobosan Cadar Perseroan dan Soal-Soal Aktual Hukum Perusahaan, Citra Aditya Bakti, Bandung, 2004, hlm. 84. 
Dari banyaknya aturan yang mengatur mengenai komisaris independen dapat disimpulkan bahwa tugas dan kriteria seorang komisaris independen akan lebih berat dari komisaris lainnya. Komisaris independen berkewajiban bersikap independen dan objektif walaupun ia dipilih oleh pemegang saham mayoritas. Selain itu, komisaris independen mempunyai peran yang penting dalam usaha melaksanakan GCG dalam suatu perseroan, komisaris independen diharapkan dapat menghilangkan praktik-praktik yang kurang baik atau tidak fair, baik terhadap pemegang saham mayoritas maupun terhadap pemegang saham minoritas. ${ }^{19}$

Dalam pedoman GCG (4.1) dinyatakan bahwa dewan komisaris wajib membentuk komite audit yang beranggotakan satu atau lebih anggota dewan komisaris. Dewan dapat meminta kalangan luar dengan berbagai keahlian, pengalaman dan kualitas lain yang dibutuhkan, untuk duduk sebagai anggota komite audit. Komite audit harus bebas dari pengaruh direksi, eksternal auditor. Dengan demikian, komite audit hanya bertanggung jawab kepada dewan komisaris. Penggantian anggota komite auditor harus mendapat persetujuan lebih dari 50\% jumlah anggota komisaris.

Komite audit memiliki peranan penting dalam corporate governance di suatu perusahaan. Keefektifan mereka dalam mengawasi pengelolaan keuangan dan mengamati proses pelaporan keuangan merupakan hal yang penting untuk mendorong adanya laporan finansial yang terpercaya. Hal ini penting untuk menumbuhkan tingkat kepercayaan investor terhadap perusahaan tersebut. ${ }^{20}$

Di Indonesia, peraturan mengenai pembentukan komite audit diatur dalam Peraturan Bapepam. Peraturan ini dibuat melalui Surat Edaran No. SE-03/PM/2000. Peraturan ini merekomendasikan bahwa setiap emiten dan perusahaan publik harus memiliki komite audit. Komite audit sekurang-kurangnya terdiri dari 3 orang yang salah satunya haruslah komisaris independen yang juga berperan sebagai ketua komite. Ketentuan-ketentuan ini telah diperbaharui melalui Surat Keputusan Ketua Bapepam Kep.41/PM/2003 terutama Peraturan Nomor IX.1.5 tentang Pembentukan dan Pelaksanaan Kerja Komite Audit.

${ }^{19}$ Ibid, hlm. 84-85.

${ }^{20}$ Lawrence A Cunningham, "A New Product for the State Corporation Law Market: Audit Committee Certifications", Berkeley Business Law Journal, Volume 1, Fall 2004, hlm. 330. 
Aturan mengenai keharusan adanya komite audit dalam perusahaan publik juga ada dalam The NYSE Listing Standard. Aturan ini menyatakan bahwa "perusahaan domestik yang mendaftarkan sahamnya dalam NYSE maka mereka harus mempunyai komite audit yang hanya terdiri dari manajemen direksi. Komite ini haruslah independen dan bebas dari segala hubungan yang dapat mempengaruhi mereka dalam pengambilan keputusan yang independen sebagai anggota komite. Walaupun standar ini mewajibkan adanya independensi bagi anggota komite audit, akan tetapi dalam standar ini tidak terdapat pedoman tentang seperti apa kualifikasi yang harus dimiliki oleh anggota komite audit atau fungsi seperti apa yang harus dilaksanakan oleh anggota komite audit. ${ }^{21}$

Komite audit pada awalnya dikembangkan pada perusahaanperusahaan besar di Amerika karena besarnya jumlah keanggotaan dewan direksi mengharuskan adanya komite khusus. Pada awal 1939, New York Stock Exchange (NYSE) meliris laporan yang berjudul Independent Audits and Audit Procedures. Laporan ini menyatakan bahwa untuk menjamin independensi auditor luar (outside auditor), maka direksi suatu perusahaan harus mengangkat atau memilih auditor independen di mana dalam praktiknya melalui komite khusus dalam dewan direksi yang terdiri dari direktur yang bukan merupakan pegawai perusahaan. ${ }^{22}$

Ketika susunan dewan direksi semakin lama semakin bertambah besar antara tahun 1940-an dan 1970-an, banyak perusahaan menyadari bahwa komite audit merupakan mekanisme aktif bagi komisaris agar dapat memenuhi tanggung jawab pengawasannya dalam area kontrol internal dan pelaporan keuangan perusahaan. Pada awal 1973-an, NYSE dalam laporan keuangannya menyatakan bahwa komite audit merupakan suatu lembaga yang sangat dibutuhkan. Oleh karena itu, maka pada Januari 1977, NYSE mengadopsi persyaratan pencatatan (listing requirement) yang menyatakan bahwa perusahaan domestik harus memiliki komite audit sebagai persyaratan utama ketika mencatatkan efeknya dalam bursa saham. ${ }^{23}$

${ }^{21}$ Kevin Iurato, "Warning! A Position on the Audit Committee Could Mean Greater Exposure to Liability: The Problems With Applying A Heightened Standard of Care to the Corporate Audit Committee", Stetson Law Review, Volume 30, Winter 2001, hlm. 981.

${ }^{22}$ Jillian M Lutzy, "Analysis of the Proposed NYSE Corporate Governance and Audit Committee Listing Requirements", DePaul Business \& Commercial Law Journal, Volume 2, Fall 2003, hlm. 100.

${ }^{23} \mathrm{Ibid}, \mathrm{hlm} .101$. 
Pada 1 Agustus 2002, NYSE kemudian mengeluarkan Corporate Governance Listing Requirements, dan aturan mengenai adanya komite audit sebagai persyaratan pencatatan dapat ditemukan dalam \& 303 of the New York Stock Exchange Listed Company Manual. Menurut § 303 setiap listed company harus memiliki kualifikasi komite audit yang memenuhi persyaratan tertentu. Seluruh anggota komite audit haruslah independen sesuai dengan definisi independen yang diatur dalam NYSE. Ketentuan ini pada dasarnya menyebutkan bahwa setiap anggota tidak boleh memiliki hubungan yang dapat berpengaruh dalam pelaksanaan kinerja komite audit. Independensi diharuskan baik dalam mental atau dalam tindakan mereka, dan kemudian anggota komite audit dihindarkan untuk memiliki hubungan dengan perusahaan yang nantinya dapat mempengaruhi pelaksanaan independensi mereka dari manajemen dan perusahaan itu sendiri. ${ }^{24}$

Keberadaan komisaris independen dan komite audit sangat penting dalam menciptakan GCG di Indonesia. Kedudukan kedua organ ini dalam perusahaan publik adalah berkaitan dengan tanggung jawab pengawasan dari dewan komisaris. Oleh sebab itu, keberadaan dari komisaris independen yang duduk dalam komite audit dan anggota komite audit, wajib untuk menaati ketentuan tentang kegiatan dari komite audit. Sebagai komite yang membantu fungsi pengawasan komisaris, komite audit memiliki fungsi dalam hal yang terkait dengan proses dan peran audit bagi perusahaan, terutama dalam pelaporan hasil audit keuangan perusahaan yang dipaparkan untuk publik.

\section{Kegagalan Penerapan GCG Pada Perusahaan Publik di Indonesia}

Pentingnya penerapan GCG dalam suatu perusahaan baru diakui oleh banyak pihak setelah terjadi skandal korporasi terbesar pada beberapa perusahaan raksasa di Amerika seperti Enron Corporation, Healthsouth, Tyco, dan WorldCom yang telah menurunkan tingkat kepercayaan investor dan publik terhadap perusahaan. ${ }^{25}$

Enron merupakan sebuah perusahaan terbesar ketujuh di Amerika Serikat. Masyarakat Amerika pada saat terjadinya peristiwa tersebut akan selalu menyempatkan diri untuk membaca artikel tentang skandal korporasi yang terbesar sepanjang sejarah Amerika Serikat. Media televisi

${ }^{24}$ Ibid, hlm. 102-103.

${ }^{25}$ Anup Agrawal dan Sahiba Chadha, "Corporate Governance and Accounting Scandals, Journal of Law and Economics, Volume 48, Oktober 2005, hlm. 371. 
maupun media cetak lainnya melaporkan secara berkesinambungan tentang bagaimana perusahaan-perusahaan bonafid seperti Enron, WorldCom, Global Crossing dan Qwest telah menyesatkan publik tentang laporan pertumbuhan keuangan dan pendapatannya, yang dipergunakan untuk menaikkan nilai saham dan mempertahankan rating perusahaan yang diberikan oleh para analis. ${ }^{26}$

Beberapa tindakan penyalahgunaan corporate governance yang dilakukan oleh para organ perusahaan tidak hanya dapat menyesatkan pemegang saham mengenai prospek dan kinerja perusahaan, tetapi juga pihak lain yang terkait seperti kreditur, pegawai, buruh, dan masyarakat. Hal ini tentu saja dapat berdampak pada menurunnya harga saham perusahaan. Para pekerja kehilangan pekerjaan, dan yang lebih ekstrim adalah perusahaan tersebut menjadi pailit. ${ }^{27}$

Di Indonesia, GCG mulai banyak diterapkan pada perusahaanperusahaan setelah terjadinya krisis moneter 1997. Para pengamat ekonomi menyatakan bahwa krisis moneter terjadi karena adanya pola praktik corporate governance yang buruk di negara-negara Asia khususnya di Indonesia. Untuk itu, sebagian besar negara Asia pada saat ini telah mulai menerima dan menyadari bahwa mereka membutuhkan suatu perbaikan atau reformasi dalam pasar, perusahaan, dan pemerintahan mereka. ${ }^{28}$

Setelah sepuluh tahun berlalu, dapat dilihat pertumbuhan negara-negara yang pernah terkena krisis moneter. Korea Selatan yang mengalami kejahatan finansial yang melibatkan para eksekutif puncak, kini telah pulih. Hal yang sama juga terlihat di Thailand dan negara-negara Asean lainnya. Sedangkan Indonesia, masih dalam proses perbaikan yang dapat dikatakan lambat.

Berdasarkan survei yang dilakukan oleh Asian Corporate Governance Association (ACGA), Pricewaterhouse Coopers, dan Mc Kinsey \& Co, menemukan beberapa persoalan yang menghambat penerapan GCG di Indonesia, antara lain: ${ }^{29}$

\footnotetext{
${ }^{26}$ Wahyono Darmabrata dan Ari Wahyudi Hertanto, "Implementasi Good Corporate Governance dalam Menyikapi Bentuk-Bentuk Penyimpangan Fiduciary Duty Direksi dan Komisaris Perseroan Terbatas", Jurnal Hukum Bisnis, Vol 22, No 6, Tahun 2003, hlm. 33.

${ }^{27}$ Daniel J.H. Greenwood, "Enronities: Why Good Corporations Go Bad", Columbia Business Law Review, 2004, hlm 774.

${ }^{28}$ David C. Kang, "The Impact of Enron on Asian Business", Vermont Law Review, Volume 27, Summer 2003, hlm. 909.

${ }^{29}$ Nindyo Pramono, op.cit., hlm. 89-90.
} 
1. Praktik-praktik perusahaan yang dibiayai oleh perbankan milik kelompok usahanya sendiri serta adanya pinjaman jangka pendek dari luar negeri. Praktik ini mempengaruhi exchange rate dan pinjaman yang digunakan untuk spekulasi dalam bidang usaha yang tidak menghasilkan devisa. Hal ini menyebabkan kesulitan perusahaan dalam mengembalikan utangnya ketika terjadi krisis moneter;

2. Dominasi pemegang saham;

3. Tidak efektifnya kinerja regulator dan lembaga-lembaga keuangan; dan

4. Lemahnya perlindungan terhadap kreditur dan investor.

Survei lain yang dilakukan oleh konsultan Asian development Bank (ADB) membuktikan bahwa 310 emiten yang tercatat di BEJ pada 20 Oktober 2001, hanya ada 8 emiten yang telah memenuhi standar GCG yang baik. Kedelapan emiten tersebut adalah PT Antam Tbk., PT Bank Universal Tbk., PT Unilever Tbk., PT Bank NISP Tbk., PT Tambang Timah Tbk., PT Bank Niaga Tbk., PT Bank Astra International Tbk., dan PT Bank BCA Tbk. ${ }^{30}$

Penilaian terhadap kelompok perusahaan tersebut dilakukan pada empat tahap aspek penting, yaitu: ${ }^{31}$

1. Hak dan tanggung jawab pemegang saham;

2. Kebijakan-kebijakan pengelolaan perusahaan;

3. Praktik pengelolaan perusahaan; dan

4. Keterbukaan.

Dengan demikian, dapat dikatakan bahwa GCG di Indonesia, khususnya pada perusahaan publik belum sepenuhnya diterapkan. Sejalan dengan hal tersebut, Komite Nasional Kebijakan Corporate Governance (KNKCG) berpendapat bahwa perusahaan-perusahaan di Indonesia mempunyai tanggung jawab untuk menerapkan standar GCG yang telah diterapkan di tingkat internasional. Namun, walau menyadari pentingnya GCG, banyak pihak yang melaporkan masih rendahnya perusahaan yang menerapkan prinsip tersebut. Masih banyak perusahaan menerapkan prinsip GCG karena dorongan regulasi dan menghindari sanksi yang ada dibandingkan yang menganggap prinsip tersebut sebagai bagian dari kultur perusahaan. Selain itu, kewajiban penerapan prinsip GCG seharusnya mempunyai pengaruh yang positif terhadap kualitas laporan keuangan yang dipublikasikan.

\footnotetext{
${ }^{30}$ Ibid, hlm. 90.

${ }^{31}$ Ibid.
} 
Lebih mendalam lagi perlu kiranya kita pahami bersama bahwa latar belakang budaya masyarakat Indonesia sangat bervariasi dan oleh karenanya dalam menerapkan prinsip-prinsip dalam lingkup bisnis termasuk pula di dalamnya pemberlakuan peraturan perundangundangan, diperlukan pendekatan yang variatif. Komunitas bisnis Indonesia sangat memerlukan perangkat hukum untuk dapat memberikan jaminan dan pemerintah telah menyikapinya dengan mengadopsi prinsip GCG. Di samping itu, pengenalan terhadap doktrin-doktrin hukum perusahaan tetap dilakukan oleh berbagai kalangan usaha maupun profesional. Meskipun berbagai upaya telah dijalankan, tetapi konsep tersebut tidak dapat dikatakan telah secara efektif terimplementasikan di seluruh wilayah Indonesia. ${ }^{32}$

Konsep budaya hukum sendiri menjadi hal yang penting bagi negara berkembang dan negara yang sedang mengalami masa transisi. Negaranegara ini seringkali mengimpor code-code ataupun sistem hukum dari legislasi negara Barat, sebagai upaya untuk memodernisasi kerangka hukum domestik mereka. Masalah muncul ketika transplantasi hukum tersebut berdampak terhadap budaya hukum domestik. Jika budaya hukum domestik tidak menerima struktur sistem hukum asing atau hukum substantif yang diimpor tersebut, maka impor sistem hukum asing tersebut tidak akan dapat diterapkan dengan sesuai. ${ }^{33}$

Konsep budaya hukum diperkenalkan oleh Lawrence M. Friedman pada 1960-an. Friedman menyebutkan sejumlah fenomena untuk menjelaskan apa yang dimaksud dengan budaya hukum. Budaya hukum mengacu kepada pengetahuan publik (public knowledge) dan sikap serta pola perilaku terhadap sistem hukum. Apa yang dirasakan dan dilakukan jika pengadilan fair? Apa yang mereka inginkan terhadap pengadilan? Dasar hukum apa yang dianggap memiliki legitimasi? Apa yang diketahui mengenai hukum secara umum?. ${ }^{34}$

Budaya hukum mengacu pada tingkah laku, nilai-nilai, cara bertindak, dan opini yang terbentuk dalam masyarakat yang berkaitan dengan

${ }^{32}$ Jimmy E. Elias, "Peranan Manajemen Risiko Strategik dalam Mendukung Good Corporate Governance," Jurnal Hukum Bisnis, Volume 23, No 3, 2004, hlm. 32.

${ }^{33}$ Benny S. Tabalujan, "Why Indonesian Corporate Governance Failed - Conjectures Concerning Legal Culture", Columbia Journal of Asian Law, Spring 2002, hlm. 164.

${ }^{34}$ Lawrance Friedman, The Legal System: A Social Science Perspective, Russel Sage Foundation, New York, 1975, hlm. 193-194. 
undang-undang dan sistem hukum. Budaya hukum merupakan salah satu komponen penting yang dapat menentukan kapan, mengapa dan bagaimana masyarakat menggunakan hukum, institusi hukum ataupun proses hukum. Sehingga dapat dikatakan bahwa budaya hukum secara keseluruhan merupakan budaya yang ada dalam masyarakat. ${ }^{35}$

Budaya hukum juga berkaitan dengan sikap orang-orang terhadap hukum, kepercayaan, ide, dan harapan mereka terhadap hukum. Dengan perkataan lain, budaya hukum ini merupakan bagian dari budaya pada umumnya yang berkaitan dengan sistem hukum atau sistem hukum dalam perspektif budaya. ${ }^{36}$

Budaya hukum Indonesia yang banyak mempengaruhi tingkah laku corporate governance di Indonesia adalah budaya patrimonialism. Patrimonialism merupakan konsep sosiologi yang dinyatakan oleh Max Weber dan mengacu pada sistem hubungan partiarkhi, di mana sosok ayah tidak hanya memiliki kekuasaan dalam kehidupan keluarga saja, tetapi juga dalam konteks sosial, bisnis, atau politik. Para pengamat banyak yang menyatakan bahwa patrimonialism memberikan banyak pengaruh dalam aspek kehidupan di Indonesia termasuk juga perkembangan hukum Indonesia. Sehingga sangat mungkin bahwa patrimonial cenderung berdampak pada corporate governance di Indonesia. ${ }^{37}$

Sebagai contoh bagaimana patrimonialism mempengaruhi corporate governance di Indonesia, yaitu keberadaan perusahaan dipandang sebagai sebuah jaringan hubungan keluarga daripada hubungan hukum. Pemberian hibah senilai US\$ 416 juta kepada Bank Duta oleh tiga pemegang sahamnya tidak lagi menjadi hal yang membingungkan karena perusahaan tersebut dipandang sebagai hubungan keluarga. Hal yang serupa juga terjadi dalam kasus bank Summa. Ketika salah satu anggota keluarganya mengalami kerugian, maka anggota keluarga yang lain akan segera membantunya. Jika sang anak memiliki utang yang jumlahnya sangat besar maka dia dapat menggunakan dana ayahnya untuk membayar utangnya tanpa ada kompensasi bagi si anak tersebut. ${ }^{38}$

\footnotetext{
${ }^{35}$ Benny S. Tabalujan, op.cit., hlm. 163.

${ }^{36}$ John Henry Merryman, The Civil Law Tradition: An Introduction to the Legal System of Western Europe and Latin America, Stanford Unviersity Press, Stanford, 1990, hlm. 2 .

${ }^{37}$ Benny S. Tabalujan, op.cit., hlm. 165.

${ }^{38}$ Ibid., hlm. 165-166.
} 
Jika budaya hukum dipandang sebagai hal yang penting yang dapat mempengaruhi corporate governance di Indonesia, maka inisiatif pembaharuan hukum harus lebih fokus pada budaya hukum dan hukum substantif. Dengan kata lain, suksesnya pembaharuan hukum di Indonesia (hal ini juga berlaku bagi negara berkembang dan negara dalam transisi ekonomi lainnya) tidak hanya tergantung pada institusi yang sehat, tetapi juga tergantung pada tindakan dan tingkah laku mental yang sesuai bagi para pihak yang mengelola, mengawasi, dan menggunakan institusi tersebut. ${ }^{39}$

Salah satu sebab dari lemahnya aplikasi GCG di Indonesia adalah berkenaan dengan penegakan hukum (law enforcement). Indonesia sebenarnya tidak kekurangan produk hukum. Secara implisit ketentuanketentuan mengenai GCG telah ada dan tersebar dalam UUPT, Undangundang Pasar Modal, Undang-Undang Perbankan dan Peraturan Perbankan, dan lain-lain. Namun penegakannya oleh pemegang otoritas, seperti Bank Indonesia, Bapepam, BPPN, Kementerian Keuangan, BUMN, bahkan pengadilan masih sangat lemah.

Penegakan hukum sangat berpengaruh terhadap perwujudan GCG. Penegakan hukum di Indonesia dianggap masih belum mencerminkan perlindungan yang menyeluruh dan belum memihak pada rasa keadilan seperti yang diharapkan masyarakat. Banyak permasalahan hukum, misalnya dalam beberapa kasus Bantuan Likuiditas Bank Indonesia (BLBI), yang diselesaikan dengan pendekatan politis dan bukan melalui pendekatan hukum. Dengan kata lain, kepentingan politik banyak mewarnai proses hukum di negeri ini. ${ }^{40}$

Sedikitnya terdapat dua faktor yang menyebabkan permasalahan corporate governance di Indonesia lebih serius dibandingkan dengan negaranegara lain. Pertama, mekanisme pengawasan perusahaan oleh pasar masih tergolong lemah. Baik untuk BUMN maupun perusahaanperusahaan yang mempunyai koneksi yang kuat, pengembangan strategi dan posisi kompetitif tidak didasarkan pada efisiensi dan kinerja finansial, tetapi didasarkan jaringan hubungan personal dengan struktur kekuasaan. Kedua, korupsi di Indonesia tergolong sangat akut. Korupsi di lembaga pemerintah, legislatif, dan di lembaga peradilan membuat penegak hukum nyaris tidak mampu berbuat banyak. ${ }^{41}$

${ }^{39}$ Ibid., hlm. 166.

${ }^{40}$ Antonius Alijoyo dan Subarto Zaini, op.cit., hlm. 34.

${ }^{41}$ Mas Achmad Daniri, "Reformasi Corporate Governance di Indonesia”, Jurnal Hukum Bisnis, Volume 24, No 3, Tahun 2005, hlm. 24. 
Harus diakui bahwa dalam praktiknya memang tidak mudah menciptakan iklim GCG pada perusahaan. Banyaknya persoalanpersoalan dalam perusahaan yang muncul menyebabkan penerapan GCG di Indonesia dapat dikatakan gagal. Persoalan yang paling utama adalah mengenai perlindungan pemegang saham minoritas di Indonesia yang masih lemah. Walaupun konsep ini sudah termuat dalam Pedoman GCG, tetapi hal ini belum terlaksana dengan baik. Pemegang saham minoritas seringkali mendapatkan perlakuan yang kurang adil oleh Pemegang saham mayoritas dan pengurus perseroan.

Ada tiga faktor yang menyebabkan pemegang saham minoritas mendapatkan perlakuan tidak adil tersebut, antara lain: ${ }^{42}$

1. Kurangnya ketentuan-ketentuan dalam peraturan perundangundangan yang melindungi hak-hak pemegang saham minoritas. Pada kenyataannya, sekalipun ketentuan-ketentuan tersebut ada, tetapi dirasakan masih belum cukup. Hal ini terbukti dari seringnya pemegang saham minoritas yang dirugikan kepentingannya oleh pemegang saham mayoritas yang beriktikad buruk. Selain itu, adanya kewenangan yang diberikan oleh UUPT kepada organ RUPS untuk menetapkan kebijakan perseroan, secara tegas tidak mengatur adanya kewajiban partisipasi aktif bagi pemegang saham minoritas untuk mengajukan pendapatnya.

2. Sikap dan perilaku pemegang saham mayoritas, direksi atau komisaris yang memiliki karakter moral hazard.

3. Posisi lemah dari pemegang saham minoritas karena kurangnya modal, pengetahuan, keterampilan dan kemampuan untuk mengelola PT, sehingga pemegang saham minoritas tersebut tidak mampu untuk menghadapi sikap dan perilaku dari pemegang saham mayoritas yang memiliki iktikad tidak baik.

Persoalan lain yang menghambat penerapan GCG yaitu mengenai kinerja komite audit pada perusahaan. Komite audit seringkali mendapat banyak hambatan dalam menjalankan tugas dan tanggung jawabnya untuk mendorong iklim GCG di perusahaan tempat mereka bertugas. Anggota komite audit yang bukan berasal dari eksekutif perusahaan belum cukup diberi keleluasaan dalam tugasnya dan kadang komite audit masih tunduk di bawah pengaruh dewan komisaris. ${ }^{43}$

\footnotetext{
${ }^{42}$ Misahardi Wilamarta, op.cit., hlm. 88-89.

${ }^{43}$ Kompas, 8 Oktober 2006, "Tata Kelola Perusahaan Baik, Daya Tawar Naik".
} 
Komisaris independen PT. Indofood Sukses Makmur Wahjudi Prakarsa menyatakan bahwa ada kesan komite audit hanya menerima saja laporan keuangan yang disodorkan perusahaan. Kalaupun memberikan masukan atau kritik, hal tersebut hanyalah atas apa yang direferensikan dalam laporan, bukan atas penyelidikan sendiri dan ada kesan bahwa pengaruh kekuasaan eksekutif lebih besar daripada komite audit. ${ }^{44}$

Ketidakefektifan komite audit di Indonesia dapat terlihat dari gagalnya peran komite audit pada perusahaan swasta dan BUMN, khususnya perusahaan publik. Hal ini disebabkan oleh adanya legitimasi, kualitas anggota, tugas dan tanggung jawab komite audit yang belum jelas, tidak lancarnya aliran komunikasi antara dewan komisaris, dewan direksi, dan komite audit, peran komisaris yang oportunis, serta pemahaman fungsi komite audit yang rendah.

Komisaris independen dalam perusahaan juga membawa persoalan yang tidak kalah rumitnya. Hal itu terkait dengan independensi komisaris independen yang patut dipertanyakan lebih lanjut. Anggota dewan komisaris adalah pihak yang sama dengan anggota direksi. Keadaan seperti ini tidak hanya ada pada perusahaan kecil tetapi juga perusahaan besar yang sahamnya diperdagangkan di bursa efek. Dari perspektif perusahaan yang go public dapat diketahui beberapa perusahaan di mana terdapat hubungan keluarga antara anggota dewan direksi dengan anggota dewan komisaris. Seorang direktur perusahaan induk menjadi komisaris pada perusahaan anak, dan sebaliknya direktur dari perusahaan anak menjadi komisaris pada perusahaan induk. ${ }^{45}$

Hubungan antara ketiga organ perseroan tidak ditentukan oleh besar dan kecilnya perseroan, tetapi lebih banyak dipengaruhi unsur-unsur yang mendominasi perseroan, yaitu pihak yang memiliki saham dengan jumlah besar. Selain itu, pertimbangan secara historis mengenai pemilikan perseroan yang tetap ingin menguasai perseroan sepenuhnya, walaupun sebagian sahamnya telah dimiliki pihak lain. Tidak berbeda dengan perseroan keluarga yang kecil di mana ketiga organ tidak dapat dipisahkan. Ayah menjadi komisaris utama, ibu menjadi anggota dewan komisaris, sedangkan anak-anaknya menjadi direktur utama dan direktur sebagaimana disebutkan dalam akta pendirian, dan semuanya menjadi

${ }^{44}$ Ibid.

${ }^{45}$ Moenaf H. Regar, Dewan Komisaris Peranannya sebagai Organ Perseroan, Bumi Aksara, Jakarta, 2000, hlm. 62 
pemegang saham, dan akhirnya semua menjadi komisaris dan direktur. ${ }^{46}$

Keadaan yang serupa ini bukan yang luar biasa, bahkan pada perseroan yang telah menjual sahamnya di Bursa Efek dijumpai hal yang sama seperti ini. Peranan dewan komisaris untuk melakukan pengawasan terhadap direksi praktis tidak ada, karena tidak diperlukan. Fungsi pengawasan hanya ada manfaatnya dan menjadi efektif bila yang melakukan pengawasan adalah pihak yang bebas dan tidak berpihak kepada pemimpin perusahaan dan mempunyai kemampuan yang diperlukan. Kalau tidak, pengawasan menjadi percuma, bahkan tidak bermanfaat. Dewan komisaris yang seperti ini hanya untuk memenuhi persyaratan formalitas yang disebut dalam peraturan perundangundangan. Dengan demikian maka fungsi pengawasan dewan komisaris menjadi tidak efektif. ${ }^{47}$

Dengan demikian, dapat dikatakan bahwa komisaris pada umumnya tidak efektif dalam menjaga kepentingan-kepentingan para pemegang saham. Hal ini disebabkan pemegang saham berdasarkan hubungan keluarga mempunyai posisi yang dominan. Mekanisme pengendalian (checks and balances), seperti mewakili kepentingan pihak ketiga melalui komisaris independen dan komite independen untuk penggajian (remuneration committee) dan nominasi (nomination committee) serta komite audit belum ada. Transparansi dalam kenyataannya masih sangat kurang karena praktik-praktik pengungkapan, standar-standar akuntansi serta pelaksanaannya masih belum memadai. ${ }^{48}$

Persoalan lain yang patut dijadikan pembahasan yaitu terkait dengan two-tier board system yang dianut oleh Indonesia. Walaupun Indonesia menganut two-tier boars system di mana terdapat pemisahan yang tegas antara komisaris dan direksi, akan tetapi dalam praktiknya seringkali pemisahan tersebut tidak berjalan dengan baik. Akibatnya terkesan perusahaan-perusahaan di Indonesia menganut one-tier board system di mana komisaris atau direksi mengendalikan perusahaan dengan kuat dan menjadikan salah satu pihak hanya sebagai pajangan semata hanya untuk memenuhi kriteria undang-undang. ${ }^{49}$

\footnotetext{
${ }^{46}$ Ibid

${ }^{47}$ Ibid

${ }^{48}$ www.fcgi.or.id/indonesia, diakses pada tanggal 16 Januari 2007

${ }^{49}$ Antonius Alijoyo dan Subarto Zaini, op.cit., hlm. 39.
} 
Untuk itu, maka kedua organ harus independen satu dengan yang lain. Komisaris harus dapat melakukan fungsi pengawasan yang independen terhadap direksi. Sebaliknya, direksi harus dapat pula mengelola perusahaan sehari-hari secara independen dan tanpa adanya tekanan yang berlebihan dari komisaris. Hanya dengan demikian, maka tujuan dasar pemisahan kedua organ tersebut oleh undang-undang dapat tercapai dalam rangka untuk mewujudkan mekanisme check and balances yang diperlukan dalam pengelolaan perusahaan yang sehat. ${ }^{50}$

Dalam pengalaman korporasi-korporasi di Indonesia, komisaris memiliki kecenderungan yang bisa membiaskan independensinya. Kecenderungan tersebut antara lain: ${ }^{51}$

1. Peran komisaris yang terlalu kuat dalam perusahaan

Kecenderungan ini dapat terjadi karena komisaris mewakili pemegang saham mayoritas dan atau sebagai pemegang saham mayoritas itu sendiri, sehingga dalam hal ini sering kali komisaris mengintervensi direksi dalam menjalankan tugasnya. Akibatnya efektivitas direksi dalam mengambil keputusan yang bersifat teknis menjadi terhambat, bahkan bisa jadi tidak melibatkan direksi sama sekali dalam proses pengambilan keputusan perusahaan.

2. Peran komisaris yang lemah dalam melaksanakan fungsinya

Kecenderungan lemahnya komisaris dalam melaksanakan fungsinya ini dapat terjadi karena dipengaruhi oleh beberapa faktor sebagai berikut:

a. Kedudukan direksi yang sangat kuat

Kedudukan direksi yang kuat ini dimungkinkan karena direksi mewakili pemegang saham mayoritas atau sebagai pemegang saham mayoritas itu sendiri. Dalam hal ini direksi seringkali enggan membagi wewenangnya, serta tidak memberikan informasi yang cukup. Sehingga tidak ada perencanaan dan mekanisme pengawasan terhadap manajemen.

b. Kompetensi dan integritas komisaris yang lemah

Pengangkatan komisaris yang tidak didasarkan pada kompetensi dan integritas. Misalnya pengangkatan komisaris hanya didasarkan rasa penghargaan semata, atau karena adanya hubungan pertemanan atau kekeluargaan atau bahkan pengangkatan mantan atau pejabat

\footnotetext{
${ }^{50} \mathrm{Ibid}$.

${ }^{51} \mathrm{Ibid}, \mathrm{hlm} .33-34$.
} 
pemerintah yang masih aktif dengan tujuan agar mempunyai akses ke instansi pemerintah yang bersangkutan. Dalam hal ini, bukannya tidak mungkin bahwa para komisaris tersebut bertindak sekedarnya karena keterbatasan kompetensi mereka atau karena adanya benturan kepentingan.

c. Komisaris di berbagai perusahaan

Seringkali terjadi bahwa komisaris menduduki posisi yang sama di beberapa perusahaan sekaligus. Akibatnya komitmen dan alokasi waktu mereka terhadap suatu perusahaan menjadi tidak memadai dan pengawasannya menjadi tidak efektif.

Di samping itu, lemahnya perlindungan bagi kreditur di Indonesia juga merupakan satu masalah yang perlu diperhatikan lebih lanjut. Lemahnya perlindungan dikarenakan, Pertama, posisi dan peranan kreditur di dalam corporate governance masih lemah dikarenakan pengelolaan perusahaan masih sangat kurang baik, baik oleh para kreditur maupun pengelolaan bank-bank itu sendiri. Pengendalian intern yang lemah dan kerangka-kerangka pengaturan yang kurang memadai bagi bank dan lembaga-lembaga keuangan non-bank lainnya. Ditambah lagi dengan sistem manajemen risiko intern bank yang tampaknya belum dikembangkan menjelaskan hal tersebut. Kedua, pengamatan pasar masih kurang dikarenakan pihak kreditur dan pesaing sering merupakan bagian dari konglomerat-konglomerat yang dimiliki oleh keluarga yang sama. Keluarga tersebut juga ikut memiliki perusahaan-perusahaan pemberi pinjaman dana. Ketiga, perlindungan hukum bagi kreditur masih lemah akibat sistem peradilan yang tidak efisien di Indonesia. Lagi pula, undangundang kepailitan dan prosedur-prosedurnya pada umumnya tidak aktif di Indonesia, baik dalam melindungi pihak kreditur maupun dalam menjatuhkan sanksi terhadap pihak peminjam. ${ }^{52}$

Persoalan lain yang dihadapi dalam implementasi GCG adalah rendahnya transparansi. Transparansi merupakan salah satu prinsip dasar GCG, sedangkan akar budaya Indonesia belum terbiasa dengan transparansi atau keterbukaan. Masalah ini muncul ketika transparansi bukan hanya menyangkut pemberian gaji kolektif komisaris atau direksi tetapi termasuk kewajiban untuk merinci segala bentuk manfaat yang diterima masing-masing anggota kedua dewan tersebut. Demikian pula

\footnotetext{
${ }^{52}$ www.fcgi.or.id/indonesia, diakses tanggal 16 Januari 2007.
} 
dengan pengungkapan agenda rapat dan tingkat kehadiran komisaris dan direksi, pengungkapan laporan keuangan, pengungkapan adanya perbedaan pendapat (dissenting mechanism) antar komisaris dan direksi, dan pengungkapan hal yang bersifat sensitif seperti pengungkapan kegagalan belum sepenuhnya dibuka untuk publik secara luas. ${ }^{53}$ Demikian juga akses untuk memperoleh informasi mengenai perusahaan dengan mudah oleh pemegang saham juga belum sepenuhnya terakomodasi dengan baik.

Dengan banyaknya berbagai permasalahan dalam perusahaan di Indonesia, maka dapat dikatakan bahwa penerapan GCG di Indonesia gagal. Perusahaan publik belum sepenuhnya bersedia untuk menjalankan prinsip-prinsip GCG dalam perilaku dan kegiatan pengelolaan perusahaan sehari-hari. GCG sendiri tidak serta merta dapat diterapkan secara baik oleh pihak-pihak yang ada dalam perusahaan itu sendiri, tetapi perlu adanya dukungan dari pihak regulator untuk membuat suatu payung hukum yang menaungi penerapan GCG. Payung hukum ini digunakan untuk mengarahkan dan mengelola bisnis dan urusan-urusan perusahaan dalam rangka meningkatkan akuntabilitas dan realibilitas perusahaan yang bertujuan untuk meningkatkan nilai pemegang saham dalam jangka panjang dengan tetap memperhatikan kepentingan para stakeholder yang lainnya. Diakui ataupun tidak implementasi GCG di Indonesia merupakan hal yang sangat vital, karena dapat membantu perusahaan keluar dari krisis ekonomi dan bermanfaat bagi perusahaan-perusahaan Indonesia yang harus menghadapi arus globalisasi, mengikuti perkembangan ekonomi global dan pasar dunia yang kompetitif.

\section{Penutup}

Penerapan GCG pada perusahaan publik di Indonesia dapat dikatakan gagal untuk diterapkan. Padahal, kehadiran GCG di Indonesia merupakan hal yang vital sebagai salah satu solusi untuk menciptakan kegiatan berusaha yang kondusif dan dapat menghindarkan segala bentuk skandal dalam suatu perusahaan, terutama di Indonesia yang merupakan negara dengan budaya korupsi yang sangat tinggi dan etika berusaha yang rendah.

\footnotetext{
${ }^{53}$ Antonius Alijoyo dan Subarto Zaini, op.cit., hlm. 35.
} 
GCG tidak serta merta dapat diterapkan secara baik oleh pihakpihak yang ada dalam perusahaan itu sendiri, tetapi perlu adanya dukungan dari pihak regulator untuk membuat suatu payung hukum yang menaungi penerapan GCG. Untuk itu, sebaiknya prinsip-prinsip GCG dibuat dalam bentuk ketentuan perundang-undangan agar memiliki kekuatan hukum mengikat, mengingat sampai saat ini ketentuan mengenai GCG yang dibuat oleh Komite Kebijakan Nasional Corporate Governance hanya dalam bentuk rekomendasi. Oleh karena selama ini prinsip-prinsip GCG hanya berbentuk rekomendasi, maka perusahaan masih enggan untuk menerapkan GCG secara penuh.

\section{Daftar Pustaka}

Agrawal, Anup dan Chadha, Sahiba, Oktober 2005, "Corporate Governance and Accounting Scandals, Journal of Law and Economics, Volume 48. Alijoyo, Antonius dan Zaini, Subarto, 2004, Komisaris Independen, Penggerak Praktik GCG di Perusahaan, Penerbit PT Indeks Kelompok GRAMEDIA, Jakarta.

Balfas, Hamud M., 2006, Hukum Pasar Modal Indonesia, PT Tatanusa, Jakarta.

Chatamarrasjid, 2004, Penerobosan Cadar Perseroan dan Soal-Soal Aktual Hukum Perusahaan, Citra Aditya Bakti, Bandung.

Cunningham, Lawrence A, Fall 2004, "A New Product for the State Corporation Law Market: Audit Committee Certifications", Berkeley Business Law Journal, Volume 1.

Daniel J.H Greenwood, 2004, “Enronities: Why Good Corporations Go Bad", Columbia Business Law Review.

Daniri, Mas Achmad, Tahun 2005, "Reformasi Corporate Governance di Indonesia", Jurnal Hukum Bisnis, Volume 24, No 3.

Darmabrata, Wahyono dan Hertanto, Ari Wahyudi, Tahun 2003, “Implementasi Good Corporate Governance dalam Menyikapi BentukBentuk Penyimpangan Fiduciary Duty Direksi dan Komisaris Perseroan Terbatas", Jurnal Hukum Bisnis, Vol 22, No 6.

Elias, Jimmy E., 2004, "Peranan Manajemen Risiko Strategik dalam Mendukung Good Corporate Governance," Jurnal Hukum Bisnis, Volume 23, No 3.

Friedman, Lawrance, 1975, The Legal System: A Social Science Perspective, Russel Sage Foundation, New York. 
Greenwood, Daniel J.H., 2004, “Enronities: Why Good Corporations Go Bad", Columbia Business Law Review.

Iurato, Kevin, Winter 2001, “Warning! A Position on the Audit Committee Could Mean Greater Exposure to Liability: The Problems With Applying A Heightened Standard of Care to the Corporate Audit Committee", Stetson Law Review, Volume 30.

Kang, David C., Summer 2003, “The Impact of Enron on Asian Business”, Vermont Law Review, Volume 27.

Kompas, 8 Oktober 2006, “Tata Kelola Perusahaan Baik, Daya Tawar Naik

Lazarev, Nikolai, 2006, "On Certain Issues of The Modern Corporate Governance Reform in Russia", International Company and Commercial Law Review, Volume 17 (5).

Lutzy, Jillian M, Fall 2003, “Analysis of the Proposed NYSE Corporate Governance and Audit Committee Listing Requirements", DePaul Business \& Commercial Law Journal, Volume 2.

Merryman, John Henry, 1990, The Civil Law Tradition: An Introduction to the Legal System of Western Europe and Latin America, Stanford Unviersity Press, Stanford.

Pramono, Nindyo, 2006, Bunga Rampai Hukum Bisnis Aktual, PT Citra Aditya Bakti, Bandung.

Regar, Moenaf H., 2000, Dewan Komisaris Peranannya sebagai Organ Perseroan, Bumi Aksara, Jakarta.

Safitri, Indra, Indonesia Market Links Network, 2-9-2002

Sjahdeni, Sutan Remi, 2000, “Peranan Fungsi Kepengawasan bagi Pelaksana Good Corporate Governance," Reformasi Hukum di Indonesia Sebuah Keniscayaan, R.M. Talib Puspokusumo (ed), Tim Pakar Hukum Departemen Kehakiman dan Hak Asasi Manusia Republik Indonesia, Jakarta.

Salacuse, Jeswald W., 2004, "Corporate Governance in the New Country", Company Lawyer, Volume 25 (3).

Surya, Indra dan Yustiavandana, Ivan, 2006, Penerapan Good Corporate Governance Mengesampingkan Hak-Hak Istimewa demi Kelangsungan Usaha, Kencana, Jakarta.

Tabalujan, Benny S., Spring 2002, “Why Indonesian Corporate Governance Failed - Conjectures Concerning Legal Culture", Columbia Journal of Asian Law. 
Wilamarta, Misahardi, 2002, Hak Pemegang Saham Minoritas dalam Rangka Good Corporate Governance, Program Pasca Sarjana, Fakultas Hukum Universitas Indonesia, Jakarta.

www.fcgi.or.id/indonesia, diakses pada tanggal 16 Januari 2007 Vanderloo, Jeremy Charles, Fall 2004, “Encouraging Corporate Governance for the Closely Held Business", Mississippi College Law Review, Volume 24. 